\title{
Mutation analysis of the RPGR gene reveals novel mutations in south European patients with $\mathrm{X}$-linked retinitis pigmentosa
}

\author{
${ }^{1}$ International Institute of Genetics and Biophysics, CNR, Naples, Italy \\ ${ }^{2}$ Department of Genetics, Fundacion Jimenez Diaz, Madrid, Spain \\ ${ }^{3}$ Department of Medical Genetic, University of 'La Sapienza', Rome, Italy \\ ${ }^{4}$ Eye Clinic, Second University of Naples, Italy \\ ${ }^{5}$ CSS-Mendel Institute, Tor Vergata University, Rome, Italy \\ ${ }^{6}$ Eye Clinic, IRCCS 'San Matteo', Pavia, Italy \\ ${ }^{7}$ Unidad de Genetica, Hospital La Fe, Valencia, Spain \\ ${ }^{8}$ Unidad de Genetica, Hospital 'Virgen del Rocio', Seville, Spain \\ ${ }^{9}$ General Biology and Medical Genetics, University of Pavia, Italy \\ ${ }^{10}$ Servei de Genetica, Hospital Sant Pau, Barcelona, Spain
}

Maria Giuseppina Miano ${ }^{1}$, Francesco Testa ${ }^{1,4}$, Maria Strazzullo ${ }^{1}$, Mariajose Trujillo ${ }^{2}$, Carmelilia De Bernardo ${ }^{3}$, Barbara Grammatico ${ }^{3}$, Francesca Simonelli, Massimo Mangino ${ }^{5}$, Isabella Torrente ${ }^{5}$, Giulio Ruberto ${ }^{6}$, Magdalena Beneyto ${ }^{7}$, Guillermo Antinolo ${ }^{8}$, Ernesto Rinaldi ${ }^{4}$, Cesare Danesino ${ }^{9}$, Valerio Ventruto ${ }^{1}$, Michele D’Urso ${ }^{1}$, Carmen Ayuso ${ }^{2}$, Monserrat Baiget ${ }^{10}$ and Alfredo Ciccodicola ${ }^{1}$

\begin{abstract}
The RPGR (retinitis pigmentosa GTPase regulator) gene has been shown to be mutated in 10-20\% of patients with X-linked retinitis pigmentosa (XLRP), a severe form of inherited progressive retinal degeneration. A total of 29 different RPGR mutations have been identified in northern European and United States patients. We have performed mutation analysis of the RPGR gene in a cohort of 49 southern European males affected with XLRP. By multiplex SSCA and automatic direct sequencing of all 19 RPGR exons, seven different and novel mutations were identified in eight of the 49 families; these include three splice site mutations, two microdeletions, and two missense mutations. RNA analysis showed that the three splice site defects resulted in the generation of aberrant RPGR transcripts. Six of these mutations were detected in the conserved amino-terminal region of RPGR protein, containing tandem repeats homologous to the RCC1 protein, a guanine nucleotide-exchange factor for RanGTPase. Several exonic and intronic sequence variations were also detected. None of the RPGR mutations reported in other populations were identified in our series. Our results are consistent with the notions of heterogeneity and minority causation of XLRP by mutations in $R P G R$ in Caucasian populations.
\end{abstract}

Keywords: eye diseases; retinal dystrophies; X-linked gene; retinitis pigmentosa 3 (RP3); retinitis pigmentosa GTPase regulator gene $(R P G R)$; mutation analysis

Correspondence: Dr Michele D'Urso, International Institute of Genetics and Biophysics, CNR, Via Marconi 10, 80125 Naples, Italy. Tel:/Fax: + 390817257247 ; E-mail: durso@iigbna.iigb.na.cnr.it

Received 8 December 1998; revised 17 February 1999; accepted 23 March 1999 


\section{Introduction}

$\mathrm{X}$-linked retinitis pigmentosa (XLRP) is a severe retinal degeneration that typically causes night blindness, loss of peripheral vision within the first or second decades of life, legal blindness by 30 years of age, and often complete functional blindness by 40 or $50 .^{1-3}$ At least two loci on the $\mathrm{X}$ chromosome can mutate to cause retinitis pigmentosa (RP). The first, RP2 (type 2), was recently identified by positional cloning in Xp11.3. ${ }^{4}$ A second locus, RP3 (type 3), is distal to RP2 between the DXS1110 and OTC loci in Xp21.1. ${ }^{5,6}$ RP3 is the disease locus in the majority of XLRP families. ${ }^{7-9}$ Deletion analysis and a positional sequencing approach led to the identification of the RPGR (retinitis pigmentosa GTPase regulator) gene at the RP3 locus. ${ }^{10}$ The predicted protein contains in its amino-terminal half a tandem repeat structure highly similar to RCC1 (regulator of chromosome condensation) suggesting an interaction with a small GTPase. ${ }^{10}$ Mutations within conserved domains provide evidence that $R P G R$ is the $R P 3$ gene, but its function and the etiology of retinal degeneration are unknown.

The $R P G R$ gene was shown to be mutated in only $10-15 \%$ of northern European RP3 families ${ }^{10,11}$ and in $20 \%$ of United States XLRP families. ${ }^{12}$ Most mutations fall in exons encoding RCC1 repeats, the characteristic domain of the amino-terminal region of RPGR putative protein. It is conceivable that $R P G R$ is not responsible for most cases of XLRP linked to this region and that another $R P$ novel gene(s) remains unidentified. Another possibility is that identification of RPGR mutations escape detection because they are located in regulatory regions (eg promoter regions) or in additional coding sequences. ${ }^{10,13}$ To date 29 different RPGR mutations have been identified. ${ }^{10-15}$ Most mutations identified in European families have been different from those identified in the United States. To extend the information about the range, type, and frequency of RPGR mutations in different populations, the goal of the present study was to investigate southern European patients with XLRP. We report here the examination of all 19 exons of the RPGR gene in 34 XLRP families from Spain and 15XLRP from Italy.

\section{Materials and Methods}

\section{XLRP Patients}

Patients were considered as XLRP on the basis of ocular examination, electroretinography (ERG) and assessment of visual field. ${ }^{16,17}$ Pedigrees showed no male-to-male transmission of the disease, and females were only mildly affected, consistent with X-linked inheritance. Clinical phenotypes of families XLRP-24 and XLRP-534 have been reported elsewhere. ${ }^{13}$ In six families, the disease state was linked to the RP3 locus; in the others, linkage analysis was not possible.

\section{Multiplex SSCA Screening}

Genomic DNA for amplification reactions was extracted from the blood of affected individuals and other family members by standard procedure. ${ }^{18}$ All individuals were informed about the objectives of the study and volunteered to participate. DNA samples were screened for mutations within the $R P G R$ gene, by multiplex PCR/SSCA analysis. ${ }^{19}$ The screen was performed for all 19 exons of the $R P G R$ gene, using oligonucleotide primers described elsewhere. ${ }^{10}$ Genomic DNA samples $(200 \mathrm{ng})$ were co-amplified for three pairs of RPGR primers in a $12 \mu \mathrm{l}$ reaction containing $7.5 \mathrm{mM} \mathrm{MgCl}_{2}, 7.5 \mathrm{~mm}$ Tris- $\mathrm{HCl}$ (pH 8), 7.5m м Hepes, $50 \mathrm{~mm} \mathrm{KCl,} 2$ mм DTT, $0.01 \%$ gelatin, $2.5 \%$ formamide, $6.25 \mathrm{~mm}$ dNTPs, $0.5 \mathrm{~mm}$ each primer and 0.5 units Taq polymerase (Perkin Elmer, Foster City, CA, USA). After an initial denaturation step at $94^{\circ} \mathrm{C}$ for $5 \mathrm{~min}$, PCR was performed for 30 cycles; each cycle consisted of $30 \mathrm{~s}$ of denaturation at $94^{\circ} \mathrm{C}, 45 \mathrm{~s}$ of annealing at an appropriate temperature, and $45 \mathrm{~s}$ at $72^{\circ} \mathrm{C}$ for extension; $4 \mu \mathrm{l}$ of stop solution ( $95 \%$ formamide, $60 \mathrm{~mm} \mathrm{NaOH}, 10 \mathrm{~mm}$ EDTA, $0.1 \%$ xylene cyanol and $0.1 \%$ bromophenol blue) were added to $3 \mu \mathrm{l}$ of each sample. Amplification products were denatured for $4 \mathrm{~min}$ at $95^{\circ} \mathrm{C}$, chilled in ice for $5 \mathrm{~min}$ and loaded on to SSCA gels. Gel formulations include $9 \%$ acrylamide/bis (60:1), $8 \%$ glycerol and 8\% acrylamide/bis (50:1), 6\% glycerol. Gels were run for $6-12 \mathrm{~h}$ at $4^{\circ} \mathrm{C}, 1200 \mathrm{~V}$, and stained using a silver nitrate protocol. ${ }^{20}$

\section{Reverse Transcriptase-PCR Analysis}

Total RNA was isolated by the guanidine isothiocyanatephenol method ${ }^{21}$ from Epstein-Barr virus-immortalised lymphocytes of probands of families XLRP-401, XLRP-DA, and XLRP-192. The cDNA was synthesised using random hexamers as primers and Superscript II RNase H Reverse (Life Technologies, Milan, Italy) according to the manufacturer's instructions. Subsequent amplification was done with primers: RT2 (5'-GTT TAA AAA TGA TGT CCC TGT A-3') and RT3 (5'-TTG ACA CAT GTT GGC TTG CTG A-3') for the splice site mutation in XLRP-401 (annealing $60^{\circ} \mathrm{C}$ ); RT7 (5'-GTT AGG TCT TCC CAA TCA GC-3') and RT9 (5'-TTA GAG CAC AAA GTA GGA ATG AAG-3') for the splice site mutation in XLRP-DA (annealing $60^{\circ} \mathrm{C}$ ); RT13 (5'-TTA AAA TTA TCA CCA GTT CA-3') and RT15 (5'-TTG CTC CTC TAT TCC ATT TC-3') for the splice site mutation in XLRP-192 (annealing $54^{\circ} \mathrm{C}$ ). The PCR conditions consisted of an initial denaturation at $94^{\circ} \mathrm{C}$ for $5 \mathrm{~min}$, followed by 35 cycles of denaturing at $94^{\circ} \mathrm{C}$ for $30 \mathrm{~s}$, annealing at an appropriate temperature for min and extension at $72^{\circ} \mathrm{C}$ for $2 \mathrm{~min}$, then a final extension at $72^{\circ} \mathrm{C}$ for $10 \mathrm{~min}$ with the same reagents described above.

\section{Sequencing of PCR Products}

In order to define mutations/sequence changes, DNA fragments that exhibited mobility shifts on SSCP analysis, as well as normal fragments and RT-PCR products for splice site mutations, were reamplified, gel purified using a Geneclean (Bio 101 Inc., Vista, CA, USA) gel extraction kit, and used as 
templates in a direct dideoxynucleotide chain termination reaction using dye terminator chemistry (Perkin Elmer) according to the manufacture's protocol. The primers employed for PCR reactions were used for sequencing and the products were analysed on an ABI PRISM 377 DNA sequencer (Perkin Elmer). All mutations were confirmed by sequence analysis in both directions in the affected individuals of each pedigree.

\section{Results}

In the cohort of 49 apparently unrelated XLRP families (34 Spanish and 15 Italian), seven novel mutations were identified in hemizygous affected males and heterozygous carrier females from eight XLRP families by multiplex-SSCP and direct automated sequencing. All seven mutations segregated with the disease in appropriate family members that were available for the study. Table 1 summarises the mutations observed in this study.

\section{Missense Mutations}

Two missense mutations (see Table 1) in the RCC1 domain were found in two families, one Spanish (XLRP-G9; Figure 1c) and one Italian (XLRP-RC; Figure 1d). The first (T99N) is Thr- $>$ Asn at nucleotide 355 in exon 4 (Figure $2 \mathrm{a}$ ); the second (I289V) is Ile$>$ Val at nucleotide 924 in exon 8 (Figure 2b). Both amino acidic substitutions are within residues which are conserved across evolution. ${ }^{10}$ These mutations were present in carrier females, affected males, absent in healthy males of each family and also in 120 control chromosomes suggesting that these are causative of the disease.

\section{Microdeletions}

Two different microdeletions were identified among the affected members of three unrelated families. One deletion $(\Delta \mathrm{T} 545)$, which is a single thymine deletion at base 545 in exon 6, was found in affected males of Spanish family XLRP-G4 (Figure 1f), causing a frameshift and premature termination signal in codon 174 This mutation has also been reported in another Spanish family XLRP-24, ${ }^{13}$ but the two families are unrelated - at least in available pedigrees - and came from different parts of Spain. The second (AAT296-297) was a deletion of two bases pairs at 296-297 in exon 3, causing a frameshift and premature termination signal in codon 86 . This mutation has been identified in an Italian family XLRP-534 described previously. $^{13}$

\section{Splice-site Mutations}

In three patients, splice site mutations were detected that cosegregated with the disease. The first (IVS2-2) was observed in an Italian family (XLRP-401; Figure 1b). It is an A-> G transition (Figure 3a) at position -2 , at the first intronic nucleotide of the splice-acceptor site of exon 3 (sequence designation is according to Meindl et $a l^{10}$ ). To determine the effect of this mutation, we sequenced the RT-PCR products, spanning exons 2 and 3 , from the proband lymphocyte RNA. Our results show that the mutant transcript of $606 \mathrm{bp}$ includes intron 2 , resulting in a failure to recognise the affected intron (Figure 3a). Intron 2 is therefore retained in the final mRNA product. As a result, a new stop codon is encountered within the first three nucleotides of the intron, resulting in a severely truncated polypeptide of

Table 1 RPGR mutations in patients with XLRP

\begin{tabular}{|c|c|c|c|c|c|}
\hline Mutation & Exon & $\begin{array}{l}\text { Mutation at DNA } \\
\text { level }\end{array}$ & $\begin{array}{l}\text { Mutation at RNA and protein } \\
\text { level }\end{array}$ & Family & Origin \\
\hline \multicolumn{6}{|l|}{ Missense: } \\
\hline T99N & 4 & $\mathrm{C}->\mathrm{A}$ at $355 \mathrm{nt}$ & codon 99 (Thr->Asn $)$ & XLRP-G9 & Spain \\
\hline $\mathrm{I} 289 \mathrm{~V}$ & 8 & $\mathrm{~A}->\mathrm{G}$ at $924 \mathrm{nt}$ & codon 289 (Ile->Val) & XLRP-RC & Italy \\
\hline \multicolumn{6}{|l|}{ Deletion: } \\
\hline$\Delta$ AT296-297 & 3 & del AT at 296-297 nt & frameshift and stop codon at 86 & XLRP-534 & Italy \\
\hline$\Delta \mathrm{T} 545$ & 6 & del T at $545 \mathrm{nt}$ & frameshift and stop codon at 174 & XLRP-G4 & Spain \\
\hline & & & & XLRP-24 $4^{\mathrm{a}, \mathrm{b}}$ & Spain \\
\hline \multicolumn{6}{|l|}{ Splicing: } \\
\hline IVS2-2 & 3 & $\mathrm{~A}->\mathrm{G}$ at $216-2 \mathrm{nt}$ & change in splice donor & XLRP-401 & Spain \\
\hline IVS8+1 & 8 & $\mathrm{G}->\mathrm{A}$ at $839+1 \mathrm{nt}$ & change in splice acceptor & XLRP-DA & Italy \\
\hline IVS13-2 & 14 & $\mathrm{~A}->\mathrm{G}$ at $1632-2 \mathrm{nt}$ & change in splice donor & XLRP-192 & Spain \\
\hline
\end{tabular}

Codon numbering starts with the first in-frame methionine of the $R P G R$ gene (Meindl et al $;^{10}$ ). All mutations were tested in

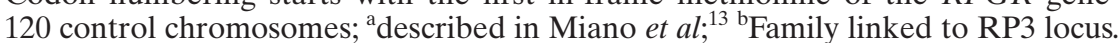




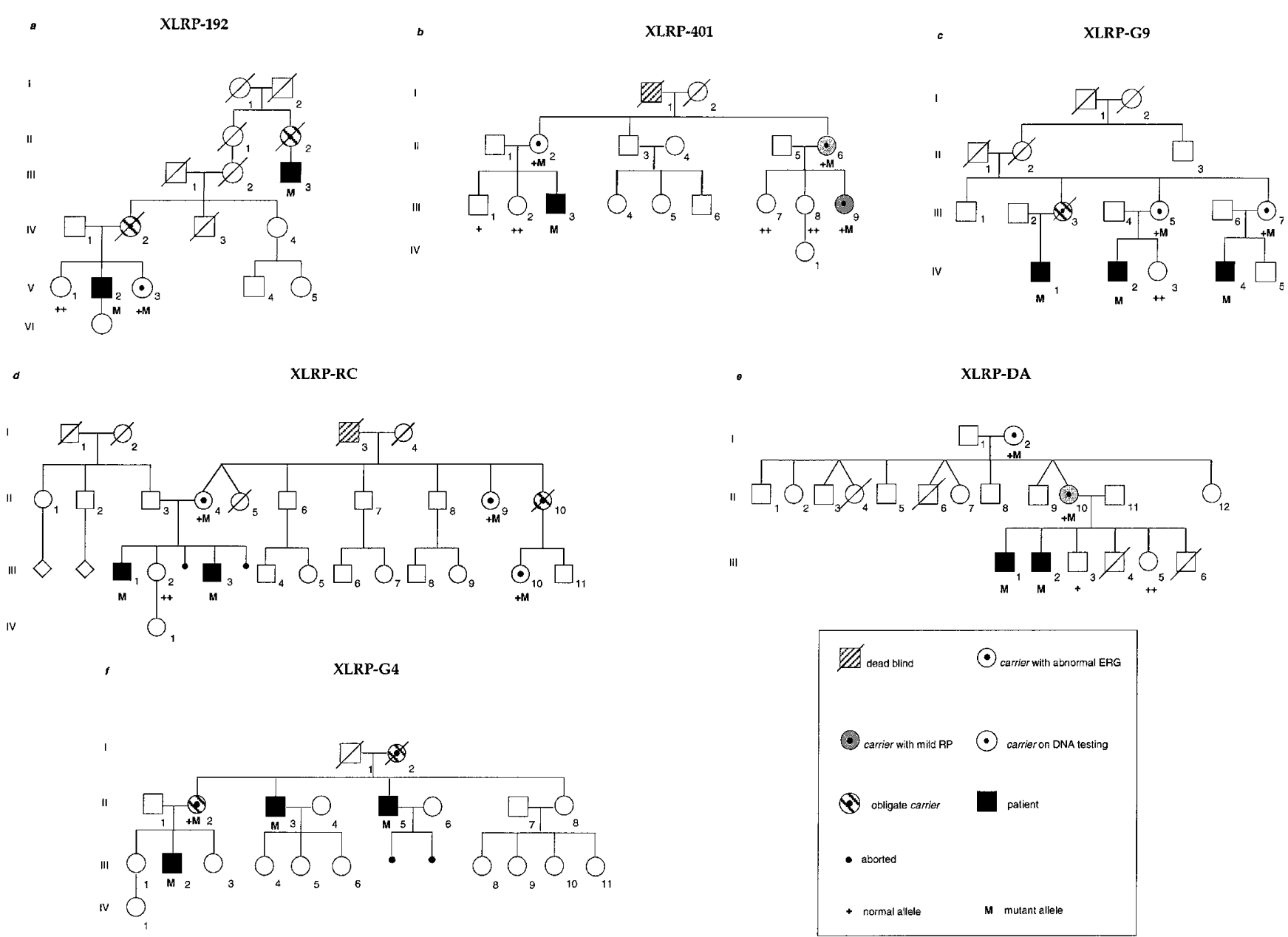

Figure 1 Segregation of RPGR mutations in six XLRP families. a) family XLRP-192 is segregating for the splice site mutation IVS13-2; b) family XLRP-401 for the IVS2-2; c) family XLRP-G9 for the T99N; d) family XLRP-RC for I289V; e) family XLRP-DA for the IVS8 + 1; and f) family XLRP-G4 for $\triangle T 545$ (See Table 1). Symbols used are described at the bottom of the figure

193 residues lacking the RCC1 domains. The sequence alteration generated a new HpaII restriction site and the loss of a BstNI restriction site, which segregate with the disease in the family (data not shown).

The second splice site mutation (IVS $8+1)$ is a G- $>$ A transition (Figure $3 b$ ) at position +1 in the splice-donor region of exon 8, observed in another Italian family, XLRP-DA (Figure 1e). Sequence analysis of RT-PCR products from lymphocyte RNA from the proband was performed with primers that span exons 7 to 9. The sequence change results in the skipping of exon $8(156 \mathrm{nt})$, and leads to an in-frame deletion of an RCC1 repeat (Figure 3b).

The third splice site mutation (IVS13-2) was observed in a Spanish family, XLRP-192 (Figure 1a). It is also an A- $>\mathrm{G}$ transition (Figure $3 \mathrm{c}$ ) at position -2 in the splice-acceptor site of exon 14. Sequence analysis of RT-PCR products from lymphocyte RNA from the proband was carried out with primers spanning exons 13 to 15 . Similar to mutation IVS $8+1$, this sequence alteration results the skipping of an exon (exon 14, 185 bp), and leads to an in-frame deletion in the carboxy-terminal region of the RPGR protein (Figure 3c). This consequence is a protein with a small 'charged domain'. 12 These three mutations were absent in 70 XLRP and 120 control chromosomes, indicating that they are not simply frequent variant alleles in these populations.

\section{Sequence Variations}

Several base substitutions (exonic and intronic) were detected by multiplex-SCCA and specified precisely by sequence analysis, in both patients and control samples 

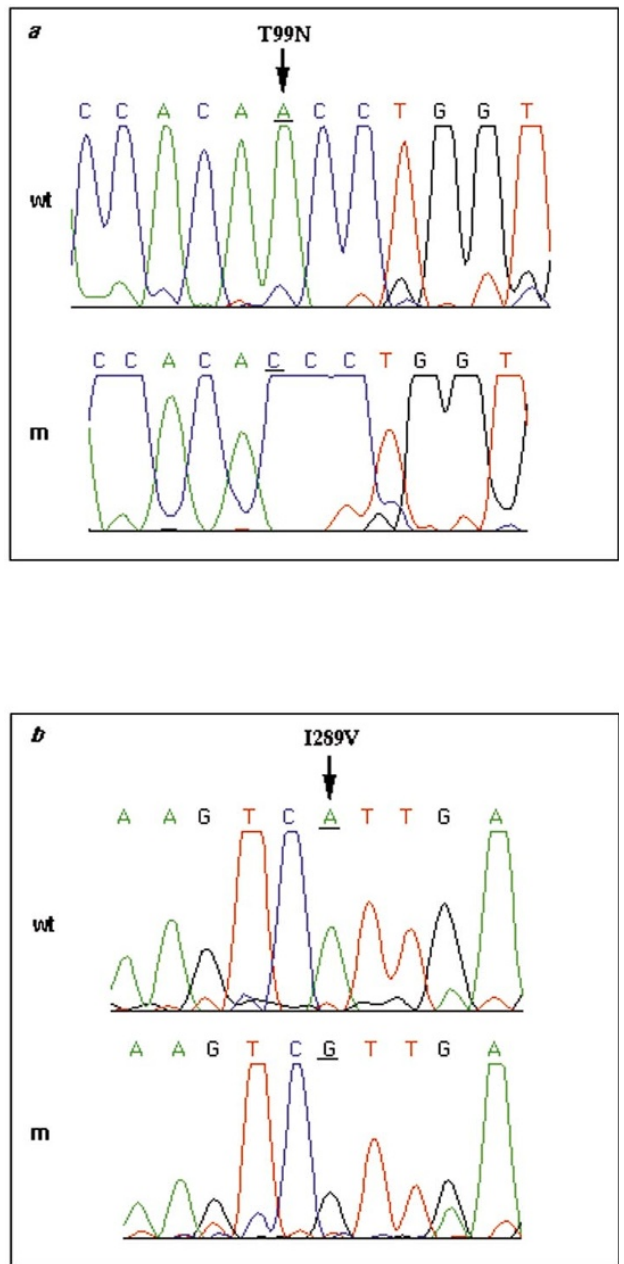

Figure 2 Sequence analysis from PCR products of patients $(m)$ and controls (wt). The PCR amplification was performed with primer pairs as described in Meindl et al ${ }^{10}$ Sequencing reactions were carried out with appropriate exon primers for mutations T99N (a) and $\mathrm{I} 289 \mathrm{~V}(\mathrm{~b})$

(see Table 2). We identified seven new sequence variants in some of 120 control chromosomes and 22 XLRP patients. They include two silent mutations in exon 2 (S47S), exon 7 (K244K) and one conservative substitution in exon $14(\mathrm{~T} 533 \mathrm{M})$ and four intronic variants in intron 10 (IVS10 + 16), intron 12 (IVS12-101; IVS12130), intron 17 (IVS17 + 46). Additional sequence variants detected during our studies have been described elsewhere. They include two silent mutations in exon 11 (R425K; I431V), in unaffected individuals, producing conservative amino acid substitutions. ${ }^{11,12} \mathrm{We}$ also identified one silent mutation in exon 10 (A388A), one conservative substitution in exon 14 (G566E), and three intronic variants in intron 1 (IVS1-15), intron 13 (IVS13 + 11), intron 18 (IVS18 + 11), all previously described by Buraczynska. ${ }^{12}$ Any affect of these changes on splicing has not been determined.

\section{Discussion}

Long-range sequencing in $\mathrm{X}$-linked retinitis pigmentosa led to the discovery of mutations in the RPGR gene. ${ }^{10}$ Expression of RPGR has been demonstrated in all neuronal layers of the retina and in RPE. The protein is seen both in cytoplasm and nucleoplasm, particularly in the vicinity of nuclear pores, in membranous organelles surrounding the nucleus and the inner and outer segments of both rod and cone photoreceptors. ${ }^{22,23}$ But all studies indicate that RPGR is expressed at surprisingly low levels in the retina, and it is unclear how mutations in this gene cause retinal degeneration.

Mutations in RPGR (see Figure 4) have been identified in only $10-15 \%$ of northern European RP3 families $^{10,11}$ and in $20 \%$ of United States XLRP families. ${ }^{12}$ The low percentage of XLRP families with RPGR mutations is consistent with recent reports indicating that RPGR mutations were found in XLRP families less frequently than the $60-90 \%$ level originally predicted by linkage analysis of XLRP pedigrees. ${ }^{7-9,12}$ Thus, other genes might be quantitatively more important as causes of XLRP. On the other hand, it remains a possible alternative that because the sensitivity of mutation-detection methods is not adequate, mutations may have escaped detection, possibly because they occur in regulatory regions (eg promoter region) or in additional coding sequences. ${ }^{10,13}$

Studies of different populations might reveal a range of mutations that would help to distinguish between these alternatives. Here, among 49 southern European XLRP families, eight carried seven different RPGR mutations in coding regions and splice sites. None of the 29RPGR mutations already reported in other populations were seen. This result demonstrates the diversity of RPGR mutations responsible for XLRP in different populations. It is consistent with the inference that most RP3 mutations are of independent origin. ${ }^{24}$

Different clinical presentations have been recognised in XLRP, ${ }^{3}$ and some genotype-phenotype correlations have been attempted in hemizygous males and heterozygous carrier female in XLRP families. ${ }^{25-27,15}$ The location and nature of RPGR mutations might help to understand the molecular basis of XLRP and the role of the RPGR protein in photoreceptor function. Six of 

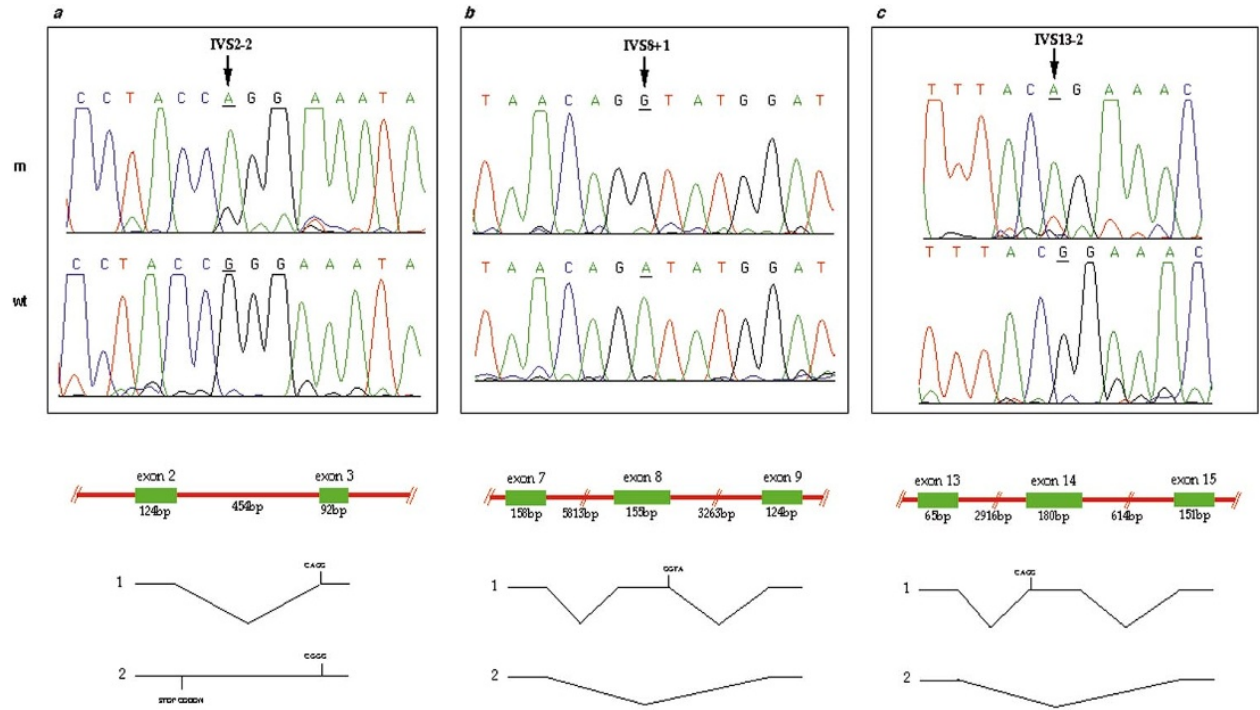

Figure 3 Sequence analysis from PCR products of patients $(m)$ and controls (wt). At the bottom: schematic representation of the effects in the three splice mutations

Table 2 RPGR sequence variations in XRLP patients

\begin{tabular}{|c|c|c|c|c|}
\hline $\begin{array}{l}\text { Sequence } \\
\text { variation }\end{array}$ & Nucleotide change & Exon/intron & Effect on coding sequence & $\begin{array}{l}\text { Frequency } \\
\text { observed }(\%)\end{array}$ \\
\hline S47S ${ }^{\mathrm{a}}$ & $\mathrm{T}$ or $\mathrm{G}$ at $200 \mathrm{nt}$ & exon 2 & Silent mutation & 4.3 \\
\hline $\mathrm{K} 244^{\mathrm{a}}$ & $\mathrm{G}$ or $\mathrm{A}$ at $791 \mathrm{nt}$ & exon 7 & Silent mutation & 3.3 \\
\hline A $388 A^{b}$ & $\mathrm{G}$ or $\mathrm{A}$ at $1223 \mathrm{nt}$ & exon 10 & Silent mutation & 11.2 \\
\hline $\mathrm{R} 425 \mathrm{~K}^{\mathrm{c}}$ & $\mathrm{G}$ or $\mathrm{A}$ at $1333 \mathrm{nt}$ & exon 11 & $\begin{array}{l}\text { Conservative substitution } \\
\text { (codon 425; Arg->Lys) }\end{array}$ & 3.4 \\
\hline I431Vc & A or $\mathrm{G}$ at $1350 \mathrm{nt}$ & exon 11 & $\begin{array}{l}\text { Conservative substitution } \\
\text { (codon } 431 \text {; Ile }>\text { Val) }\end{array}$ & 3.4 \\
\hline $\mathrm{T}_{533} \mathrm{M}^{\mathrm{a}}$ & $\mathrm{C}$ or $\mathrm{T}$ at $1657 \mathrm{nt}$ & exon 14 & $\begin{array}{l}\text { Conservative substitution } \\
\text { (codon 533; Thr->Met) }\end{array}$ & 0.1 \\
\hline G566E $\mathrm{E}^{\mathrm{d}}$ & $\mathrm{G}$ or $\mathrm{A}$ at $1756 \mathrm{nt}$ & exon 14 & $\begin{array}{l}\text { Conservative substitution } \\
\text { (codon 566; Gly-> Glu) }\end{array}$ & 5.6 \\
\hline IVS1-15 ${ }^{\mathrm{d}}$ & $\mathrm{A}$ or $\mathrm{G}$ at $87-15 \mathrm{nt}$ & intron 1 & Not determined & 1.7 \\
\hline IVS10+16 $6^{\mathrm{a}}$ & $\mathrm{A}$ or $\mathrm{G}$ at $1304+16 \mathrm{nt}$ & intron 10 & Not determined & 5.0 \\
\hline IVS12-101 ${ }^{\text {a }}$ & $\mathrm{T}$ or $\mathrm{A}$ at $1565-101 \mathrm{nt}$ & intron 12 & Not determined & 34.0 \\
\hline IVS12-130 & $\mathrm{T}$ or $\mathrm{C}$ at $1565-130 \mathrm{nt}$ & intron 12 & Not determined & 3.0 \\
\hline IVS13 $+11^{\text {d }}$ & $\mathrm{A}$ or $\mathrm{G}$ at $1631+11 \mathrm{nt}$ & intron 13 & Not determined & 3.0 \\
\hline IVS17+46 & $\mathrm{C}$ or $\mathrm{T}$ at $2208+46 \mathrm{nt}$ & intron 17 & Not determined & 2.0 \\
\hline IVS18+11 ${ }^{\mathrm{b}}$ & $\mathrm{T}$ or $\mathrm{C}$ at $2300+11 \mathrm{nt}$ & intron 18 & Not determined & 27.0 \\
\hline
\end{tabular}

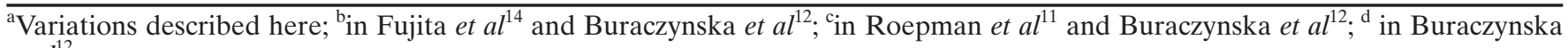
et $a l^{12}$.

the newly observed mutations, as others reported earlier, fall in RCC1 repeats and one falls in the 'charged' domain. ${ }^{12}$ The amino-terminal half of the predicted RPGR protein contains 6-7 repeats with similarity to repeats within $\mathrm{RCC} 1$, a protein which is essential for nucleocytoplasmic transport, though it might also be involved in protein trafficking through the Golgi apparatus. ${ }^{28}$ Most RPGR mutations fall in the $\mathrm{RCC1}$ repeats, providing evidence that it is an important functional domain. Recently, studies to identify proteins that interact with $R P G R$, showed that the RCC1-like domain of $R P G R$ interacts with phosphodiesterase delta subunit. ${ }^{29}$ This interaction links $R P G R$ to the visual transduction cascade that regulates the rod phosphodiesterase holoenzyme, ${ }^{30}$ though no specific related activity (eg of guanine nucleotide exchange) has been identified. The large group of XLRP families in which no mutations have been detected in RPGR provide one starting point for the study of interacting proteins or additional mutations that regulate $R P G R$. 

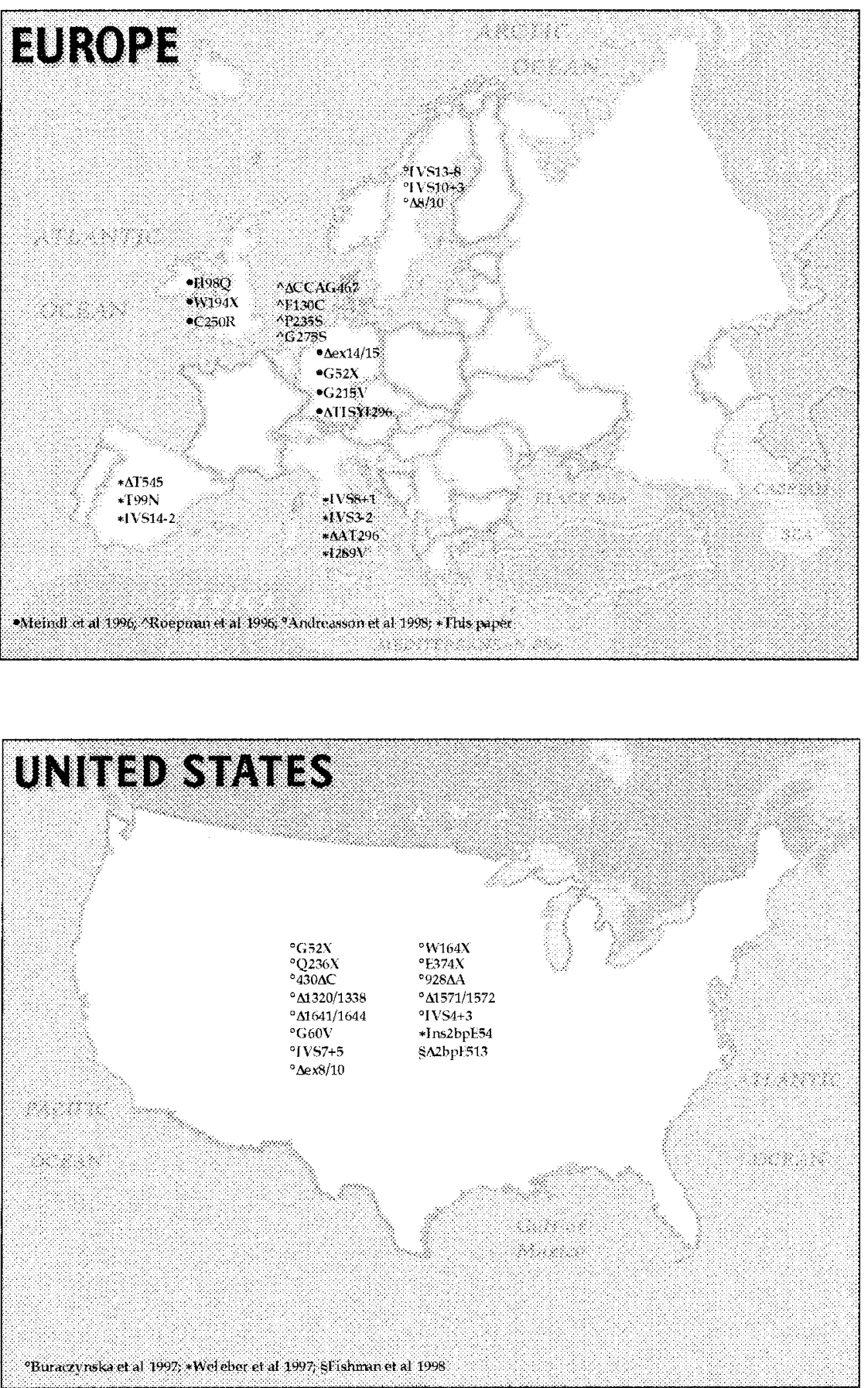

Figure 4 Distribution of RPGR mutations found in the United States and Europe

\section{Acknowledgements}

The authors would like to thank the families and their clinicians for their contributions to these studies and Dr P Danese for help in SSCA and silver stain techniques and Professors D Schlessinger, A Wright, G Novelli and B Dallapiccola for critical reading of the manuscript. Also, we are gratefully to Mrs S Cocchia for excellent technical assistance and the Sequencing Unit Core of Area di Ricerca di Napoli, CNR, where the sequences were performed. This work was supported by Telethon-Italy, grant No E546 to A Ciccodicola and grant No C18 to C Danesino. 


\section{References}

1 Weleber RG: Retinitis pigmentosa and allied disorders. In: Ryan SJ (ed. with assistance of Ogden TE). Retina: Basic Science and Inherited Retinal Disease, 2nd edn. Mosby Year Book Inc: St Louis, MO, 1994 1: 335-466.

2 Bird AC, Heckenlively JR: X-linked recessive retinitis pigmentosa (X-linked pigmentary retinopathies). In: Heckenlively JR (ed). Retinitis Pigmentosa. JB Lippincott: Philadelphia, Pa, 1988, 162-187.

3 Fishman GA, Farber MD, Derlacki DJ: X-linked retinitis pigmentosa: profile of clinical findings. Arch Ophthalmol 1988; 106: 369-375.

4 Schwahn U, Lenzner S, Dong J et al: Positional cloning of the gene for X-linked retinitis pigmentosa 2. Nat Genet 1998; 19: 327-332.

5 Brown J, Dry KL, Edgar AJ et al: Analysis of three deletion breakpoints in Xp21.1 and the further localization of RP3. Genomics 1996; 37: 200-210.

6 Seymour AB, Dash-Modi A, O'Connell JR et al: Linkage analysis of $\mathrm{X}$-linked cone-rod dystrophy: localization to Xp11.4 and definition of a locus distinct from RP2 and RP3. Am J Hum Genet 1998; 62: 122-129.

7 Musarella MA, Anson-Cartwright L, Leal SM et al: Multipoint linkage analysis and heterogeneity testing in 20 X-linked retinitis pigmentosa families. Genomics 1990; 8: $286-296$.

8 Ott J, Bhattacharya S, Chen JD et al: Localizing multiple X chromosome linked retinitis pigmentosa loci using multilocus homogeneity tests. Proc Natl Acad Sci USA 1990; 87: 701-704.

9 Teague PW, Aldred MA, Jay $\mathrm{M}$ et al: Heterogeneity analysis in $40 \mathrm{X}$-linked retinitis pigmentosa families. Am J Hum Genet 1994; 55: 105-111.

10 Meindl A, Dry K, Herrmann K et al: A gene (RPGR) with homology to the RCC1 guanine nucleotide exchange factor is mutated in X-linked retinitis pigmentosa (RP3). Nat Genet 1996; 12: 35-42.

11 Roepman $\mathrm{R}$, van Duijnhoven $\mathrm{G}$, Rosenberg $\mathrm{T}$ et al: Positional cloning of the gene for $\mathrm{X}$-linked retinitis pigmentosa 3: homology with the guanine-nucleotideexchange factor RCC1. Hum Mol Genet 1996; 5: 1035-1041.

12 Buraczynska $\mathrm{M}, \mathrm{Wu} \mathrm{W}$, Fujita $\mathrm{R}$ et al: Spectrum of mutations in the RPGR gene that are identified in $20 \%$ of families with X-linked retinitis pigmentosa. Am J Hum Genet 1997; 61: 1287-1292.

13 Miano MG, Valverde D, Solans $\mathrm{T}$ et al: Two novel mutations in the retinitis pigmentosa GTPase regulator $(R P G R)$ gene in $\mathrm{X}$-linked retinitis pigmentosa (RP3). Hum Mutat (Mutation in Brief No. 172, Online) 1998; 12: 212-213.

14 Fujita R, Buraczynska M, Gieser L et al: Analysis of the $R P G R$ gene in 11 pedigrees with the retinitis pigmentosa type 3 genotype: paucity of mutations in the coding region but splice defects in two families. Am J Hum Genet 1997; 61: $571-580$.

15 Fishman GA, Grover S, Buraczynska M, Wu W, Swaroop A: A new 2-base pair deletion in the $R P G R$ gene in a black family with X-linked retinitis pigmentosa. Arch Ophthalmol 1998; 116: 213-218.
16 Andreasson SO, Ehinger B: Electroretinographic diagnosis in families with X-linked retinitis pigmentosa. Acta Ophthalmol (Copenh) 1990; 68: 139-144.

17 Jacobson SG, Yagasaki K, Feuer WJ, Roman AJ: Interocular asymmetry of visual function in heterozygotes of X-linked retinitis pigmentosa. Exp Eye Res 1989; 48: 679-691.

18 Sambrook J, Fritsch EF, Maniatis T: Molecular Cloning: A Laboratory Manual, 2nd edn. Cold Spring Harbor Laboratory Press: New York, 1989.

19 Nigro V, Bruni P, Ciccodicola A et al: SSCP detection of novel mutations in patients with Emergy-Dreifuss muscular dystrophy: definition of a small C-terminal region required for emerin function. Hum Mol Genet 1995; 4: 2003-2004.

20 Alonso A, Martin P, Albarran C, Garcia O, Sancho M: Rapid detection of sequence polymorphisms in the human mitochondrial DNA control region by polymerase chain reaction and single-strand conformation analysis in mutation detection enhancement gels. Electrophoresis 1996; 17: 1299-1301.

21 Chomczynski P, Sacchi N: Single-step method of RNA isolation by acid guanidinium thiocyanate-phenol-chloroform extraction. Anal Biochem 1987; 162: 156-159.

22 Manson FD, Porter K, Cameron SA et al: Functional characterisation of the Retinitis Pigmentosa GTPases regulator (RPGR) protein, which is mutated in X-linked Retinitis Pigmentosa (RP3) (ARVO abstract). Invest Ophthalmol Vis Sci 1998; 39: S914. Abstract No 4207.

23 Yan D, Swain PK, Breuer D et al: Biochemical characterization and subcellular localization of the mouse retinitis pigmentosa GTPase regulator (mRpgr). J Biol Chem 1998; 273: 19656-19663.

24 Fujita R, Swaroop A: RPGR: part one of the X-linked retinitis pigmentosa story. Mol Vis 1996; 2: 4. (http:/ /www.cc.emory.edu/MOLECULAR_VISION/v2/fujita/)

25 Andreasson S, Ponjavic V, Abrahamson M et al: Phenotypes in three Swedish families with X-linked retinitis pigmentosa caused by different mutations in the $R P G R$ gene. Am J Ophthalmol 1997; 124: 95-102.

26 Jacobson SG, Buraczynska M, Milam AH et al: Disease expression in X-linked retinitis pigmentosa caused by a putative null mutation in the RPGR gene. Invest Ophthalmol Vis Sci 1997; 38: 1983-1997.

27 Weleber RG, Butler NS, Murphey WH, Sheffield VC, Stone EM: X-linked retinitis pigmentosa associated with a 2-base pair insertion in codon 99 of the RP3 gene RPGR. Arch Ophthalmol 1997; 115: 1429-1435.

28 Rosa JL, Casaroli-Marano RP, Buckler AJ, Vilaro S, Barbacid M: p619, a giant protein related to the chromosome condensation regulator RCC1, stimulates guanine nucleotide exchange on ARF1 and Rab proteins. EMBO J 1996; 15: 4262-4273.

29 Lorenz B, Migliaccio C, Lichtner P et al: Cloning and gene structure of the rod cGMP phosphodiesterase delta subunit gene (PDED) in man and mouse. Eur J Hum Genet 1998; 6: 283-290.

30 Linari M, Ueffing $\mathrm{M}$, Manson $\mathrm{F}$ et al: The retinitis pigmentosa GTPase regulator, RPGR, interacts with the delta subunit of rod cyclic GMP phosphodiesterase RCC1. Proc Natl Acad Sci USA 1999; 96: 1315-1320. 